\title{
ANALISIS FAKTOR RENDAHNYA MINAT BELAJAR MATEMATIKA SISWA KELAS V DI SD NEGERI 4 GUMIWANG
}

\author{
Bela Bekti Amallia Putri, Arifin Muslim, Tri Yuliansyah Bintaro \\ Universitas Muhammadiyah Purwokerto, Indonesia \\ belabap2582@gmail.com
}

\begin{abstract}
This study aims to find out what are the factors of low student interest in mathematics and how teachers' efforts in fostering student interest in mathematics in class $V$ at SD Negeri 4 Gumiwang. This type of research used in this study is qualitative research. This research activity was carried out by means of observation, interviews, and documentation. Types of qualitative data are data obtained from observations, interviews and documentation. Based on research that has been done, it was found that the factors of low student interest in mathematics as follows: Internal Factors of students can be shown by the lack of student love for mathematics and assume that mathematics is a difficult subject, student attention is still low on mathematics learning, and the low level of student learning persuasion in mathematics. The factor of low student interest in learning also comes from external factors. Based on the results of interviews with teachers shows that the teacher's way of teaching is still monotonous and rarely uses learning media when learning mathematics. Apart from the way the teacher teaches is also influenced by the behavior and attitudes of parents who are deemed inappropriate when dealing with students. The conclusion in this study is the efforts made by teachers in fostering student interest in learning especially in mathematics are good enough.

Keywords: Interest in Learning, Mathematics, Learning Interest Factors
\end{abstract}

\section{ABSTRAK}

Penelitian ini bertujuan untuk mengetahui apa saja faktor rendahnya minat belajar siswa pada mata pelajaran matematika dan bagaimana upaya guru dalam menumbuhkan minat belajar siswa pada mata pelajaran matematika kelas V di SD Negeri 4 Gumiwang. Jenis penelitian yang digunakan pada peneliatian ini adalah penelitian kualitiatif. Kegiatan penelitian ini dilakukan dengan cara observasi, wawancara, dan dokumentasi. Jenis data kualitatif merupakan data yang diperoleh dari hasil observasi, wawancara dan dokumentasi. Berdasarkan penelitian yang telah dilakukan, ditemukan bahwa faktor rendahnya minat belajar siswa pada mata pelajaran matematika sebagai berikut Faktor Internal siswa dapat ditunjukan dengan kurangnya rasa suka siswa terhadap mata pelajaran matematika dan beranggapan bahwa mata pelajaran matematika merupakan mata pelajaran yang sulit ,perhatian siswa yang masih rendah terhadap pembelajaran matematika, serta rendahnya perstasi belajar siswa pada mata pelajaran matematika. Faktor rendahnya minat belajar siswa juga berasal dari faktor eksternal. Berdasarkan hasil wawancara dengan guru menunjukkan bahwa cara guru dalam mengajar masih monoton dan jarang menggunakan media pembelajaran pada saat pembelajaran matematika. Selain dari cara guru mengajar juga dipengaruhi oleh perilaku dan sikap orang tua yang dirasa kurang tepat ketika terhadap siswa. Kesimpulan dalam penelitian ini adalah upaya yang dilakukan guru dalam menumbuhkan minat belajar siswa khususnya pada mata pelajaran matematika sudah cukup baik..

Kata Kunci: Minat Belajar, Matematika, Faktor Minat Belajar

Submitted October 31, 2019| Revised November 14, 2019 | Accepted November 15, 2019

\section{Pendahuluan}

Pembelajaran matematika di sekolah dasar dilakukan sesuai dengan tingkat perkembangan kognitif peserta didik. Menurut Nahdi (2017:21) mata pelajaran matematika perlu diberikan kepada semua peserta didik mulai dari sekolah dasar untuk membekali peserta didik dengan kemampuan berpikir logis, analitis, sistematis, kritis, dan kreatif, serta kemampuan bekerja sama. Kompetensi tersebut diperlukan agar peserta didik dapat memiliki kemampuan memperoleh, mengelola, dan memanfaatkan informasi untuk bertahan hidup pada keadaan yang selalu berubah, 
tidak pasti, dan kompetitif. Pada dasarnya, matematika bertujuan untuk membantu melatih pola pikir siswa agar mampu memecahkan masalah baik masalah dalam bidang matematika maupun masalah dalam kehidupan sehari-hari, namun kebanyakan siswa tidak berminat belajar matematika karena siswa memandang matematika sebagai bidang studi yang abstrak. Terkadang ada beberapa siswa yang memandang bahwa matematika hanya mampu dikuasai oleh siswa yang jenius saja. Salah satu upaya yang dapat dilakukan oleh guru dalam melatih pola pikir siswa yaitu dengan menumbuhkan minat belajar siswa dalam pembelajaran matematika (Silviani, dkk, 2017: 151). Berdasarkan teori Piaget perkembangan kognitif usia SD berada pada tahap oprasional konkret. Menurut Susanto (2013:184) pada tahap oprasional konkret peserta didik umumnya masih mengalami kesulitan dalam memahami matematika yang bersifat abstrak. Pada usia ini peserta didik baru mampu berpikir sitematis terkait dengan benda-benda dan peristiwa-peristiwa yang konkret. Oleh karena itu pada proses pembelajaran harus tercipta suasana yang nyaman dan menyenangkan serta menarik perhatian peserta didik. Pembelajaran yang menarik akan mendapat perhatian dari peserta didik, sehingga memunculkan rasa keinginan atau minat yang lebih untuk terus belajar dan memperhatikan agar memperoleh hasil yang maksimal. Dengan memiliki minat belajar yang tinggi, siswa akan mampu belajar dan berlatih matematika dengan baik, sehingga siswa akan lebih mudah untuk dilatih berpikir secara kritis, kreatif, cermat dan logis yang menjadikan siswa dapat berprestasi dengan baik dalam pelajaran matematika (Sirait, 2016:36).

Minat yang terdapat dalam diri siswa dapat dilihat dari beberapa aspek. Menurut Dalyono (2010:235) ada tidaknya minat siswa pada pelajaran dapat dilihat dari cara anak mengikuti pelajaran, lengkap tidaknya catatan, memperhatikan tidaknya dalam pelajaran itu. Minat merupakan salah satu faktor yang dapat menunjang keberhasilan dalam suatu pembelajaran. Melalui minat belajar yang tinggi siswa akan mengikuti dan memperhatikan materi pada proses pembelajaran. Perhatian siswa saat melakukan proses pembelajaran menyebabkan siswa mudah dalam memahami konsep matematika. Oleh karena itu, apabila suatu proses pembelajaran tidak sesuai dengan minat siswa maka akan memungkinkan berpengaruh negatif terhadap hasil belajar siswa. Minat merupakan sesuatu yang diawali dengan perasaan senang dan sikap positif. Minat dapat dilakukan dengan berupa bentuk perhatian yang dilakukan oleh seseorang karena ketertarikannya pada objek tersebut. Minat dapat mendorong seseorang untuk melakukan sesuatu yang disukainya. Menurut Djali (2011:121) minat adalah rasa lebih suka dan rasa ketertarikan pada suatu hal atau aktivitas tanpa ada yang menyuruh. Hal ini sejalan dengan pendapat Sukardi (Susanto, 2013:57) yang menyatakan bahwa minat dapat diartikan sebagai suatu kesukaan, kegemaran atau kesenangan akan sesuatu. Sementara menurut Hadis dan Nurhayati (2008:44) menjelaskan bahwa arti minat secara umum yaitu suatu ketertarikan yang diwujudkan oleh seseorang pada suatu objek yang disenangi. Sedangkan menurut Sardiman dalam Susanto (2013:57) minat adalah suatu kondisi yang terjadi apabila seseorang melihat ciri-ciri atau arti sementara situasi yang dihubungkan dengan keinginan-keinginan atau kebutuhan-kebutuhan sendiri. Berdasarkan dari pendapat tersebut dapat ditarik kesimpulan bahwa minat merupakan suatu keadaan dimana seseorang merasa suka dan tertarik pada suatu objek berupa benda maupun kegiatan yang sesuai dengan keinginan atau kebutuhannya. Apabila peserta didik memiliki rasa minat terhadap pembelajaran maka akan ditunjukkan melalui sikap dan perilaku yang baik pada saat proses pembelajaran. Hal ini karena minat memiliki peranan penting dalam menentukan pola 
berpikir seseorang dalam melaukakan suatu aktivitas atau tindakan. Oleh sebab itu minat merupakan salah satu faktor yang menentukan keberhasilan seseorang dalam pembelajaran.

Faktor-faktor yang mempengaruhi minat belajar siswa harus dipahami dengan baik. Hal ini karena faktor-faktor tersebut dapat memberikan pengaruh terhadap keberhasilan siswa dalam melaksanakan pembelajaran.Dengan memperhatikan faktor-faktor tersebut pembelajaran yang berlangsung, dapat berjalan dengan baik. Selain itu dapat memberikan umpan balik bagi guru dalam merefleksi atau memperbaiki pembelajaran yang selama ini telah dilakukan. Apabila mungkin selama ini dalam pembelajaran siswa terlihat kurang antusisas dan memperhatikan pada saat guru menjelaskan materi pembelajaran. Disamping itu juga dapat memberikan edukasi khususnya bagi orang tua siswa, yang mungkin terdapat beberapa kekeliruan dalam mendidik siswa dalam belajar. Sehingga perlu untuk diketahui khususnya bagi para guru dan orang tua, agar siswa dalam melakukan proses belajar dapat merasa senang dan nyaman serta dapat menumbuhkan perstasi belajar siswa. Guru merupakan sosok yang sangat berpengaruh besar terhadap hasil belajar siswa. Oleh sebab itu salah satu cara yang dapat menumbuhkan minat belajar siswa adalah upaya guru dalam melaksanakan pembelajaran. Apabila guru dapat menyampaikan pembelajaran yang baik dan menyenangkan siswa akan menjadi lebih tertarik dan antusisa dalam mengikuti pembelajaran. hal tersebut juga akan membuat siswa memiliki minat dalam mengikuti pembelajaran. Menurut Widiasworo (2017:25) menyatakan bahwa terdapat upaya yang dapat dilakukan oleh guru untuk membangkitkan minat belajar siswa diantaranya yaitu 1) Perlunya Sikap Hangat dan Kooperatif., 2) Usahakan mengawali kegiatan pembelajaran yang mengesankan., 3) Kontekstual.,4) Variasikan Metode Pembelajaran., 5)Gunakan Media Pembelajaran., 6) Ice Breaking saat jenuh., 7) Pemberian Reward.

Berdasarkan uraian diatas dapat diketahui bahwa guru memiliki pengaruh yang besar terhadap minat belajar siswa. Oleh sebab itu perlu diperhatikan dengan baik khususnya bagi guru, agar dapat membuat siswa aktif dalam proses pembelajaran, karena adanya minat yang tinggi pada saat pembelajaran. Apabila upaya tersebut dapat dilakukan dengan baik maka, pembelajaran yang berlangsung akan mudah diterima oleh siswa. Siswa menjadi merasa senang dengan pembelajaran yang berlangsung karena guru dapat memberikan suasana belajar yang dapat menarik hati siswa untuk mengikuti proses pembelajaran.

Berdasarkan hasil observasi yang telah peneliti lakukan di kelas V SD Negeri IV Gumiwang pembelajaran matematika tentang akar dan pangkat peneliti menemukan peserta didik yang tidak memperhatikan guru ketika proses pembelajaran sedang berlangsung. Terdapat peserta didik yang terlihat tidak tertarik dengan pembelajaran, lebih senang bercerita dan bermain dengan teman. Berdasarkan wawancara dengan guru prestasi peserta didik dalam pelajaran matematika masih rendah. Siswa tidak peduli dengan nilai yang diraihnya. Sudah terdapat beberapa media pembelajaran. Namun pada saat peneliti melaksanakan observasi guru belum memanfaatkan media pada saat proses pembelajaran. Berdasarkan hal tersebut peneliti beranggapan bahwa kurangnya pemanfaatan media pembelajaran, menjadikan salah satu penyebab siswa kurang tertarik dengan pembelajaran matematika.

Berdasarkan latarbelakang tersebut di atas, tujuan penelitian ini adalah 1)Untuk mengetahui faktor rendahnya minat belajar matematika siswa pada kelas V di SD Negeri 4 
Gumiwang, 2) Untuk mengungkapkan bagaimana upaya guru dalam menumbuhkan minat belajar matematika siswa kelas V di SD Negeri 4 Gumiwang.

\section{Metode Penelitian}

Jenis penelitian yang digunakan pada peneliatian ini adalah penelitian kualitiatif. Menurut Ali dan Asrori (2014:121) menyatakan bahwa penelitian kualitatif merupakan penelitian yang bersifat alami dengan pendekatan pada suatu fenomena atau gejala. Hal ini sejalan dengan penelitian yang akan dilakukan oleh peneliti, karena judul yang peneliti angkat lebih mengarah pada pendeskripsian sesuatu.

Pada penelitian ini peneliti akan melaksanakan penelitian di sekolah tepatnya di SD Negeri 4 Gumiwang kelas V pada semester genap tahun ajaran 2018/2019. Subjek dalam penelitian ini yaitu siswa. Subjek dalam penelitian ini akan memberikan informasi yang diperlukan oleh peneliti dalam melakukan penelitian.

Sumber data yang diperoleh dalam penelitian ini menggunakan teknik snowball sampling. Menurut Sugiyono (2010:125) menjelaskan bahwa snowball sampling adalah teknik penentuan sampel yang mula-mula jumlahnya kecil, kemudian membesar. Teknik atau metode dalam pengumpulan data pada penelitian inya yaitu wawancara, observasi dan dokumentasi.

Teknik analisis data pada penelitian ini yaitu dengan model Miles and Huberman. Menurut Miles and Hubermen dalam Sugiyono (2010:337) dalam aktivitas analisis data kualitatif dilakuakan secara interaktif dan berlangsusng terus-menerus samapai datanya sudah jenuh. Aktivitas dalam melakukan analisis data dengan menggunakan model Miles and Huberman yaitu data reduction (pemilihan data), data display (penyajian data), dan conclusion drawing/veryvication (kesimpulan).

Uji keabsahan data dalam penelitian ini menggunakan tianggulasi sumber dan trianggulasi teknik. Trianggulasi sumber digunakan untuk menguji kredibilitas sumber dengan cara mengecek data yang diperoleh dari berbagai sumber. Uji kredibilitas pada penelitian ini yaitu tentang faktor rendahnya minat belajar siswa pada mata pelajaran matematika, maka pengumpulan data dan pengujiannnya dilakukan pada peserta didik kelas $\mathrm{V}$, guru kelas $\mathrm{V}$, dan orang tua peserta didik. Sementara trianggulasi merupakan uji kredibilitas data yang digunakan untuk mendapatkan data. Pada penelitian ini teknik untuk menguji data dengan menggunakan wawancara, observasi dan dokumentasi. Data hasil wawancara kemudian dicek dengan data hasil observasi dan dokumentasi.

\section{Hasil dan Pembahasan}

1. Faktor Minat Belajar Matematika Siswa

Minat belajar dapat disebabkan oleh beberapa faktor. Hasil dari penelitian ini terdapat dua faktor rendahnya minat siswa pada mata pelajaran matematika. Menurut Syah (2011:145) menggolongkan dua faktor yang mempengaruhi minat belajar siswa yaitu faktor internal dan faktor eksternal. Faktor internal terdiri dari aspek fisiologis dan aspek psikologis. Berdasarkan hasil wawancara dengan siswa,guru dan orang tua siswa serta obeservasi yang dilakukan oleh peneliti, dapat disimpulkan bahwa kondisi kesehatan pada siswa kelas $\mathrm{V}$ termasuk baik. Hal ini dapat dibuktikan dari hasil wawancara yang dilakukan oleh peneliti. Sebagian besar siswa dalam kondisi sehat. Aspek Fisiologis menurut Syah (2011:145) yaitu merupakan kaeadaan atau kondisi 
jasmani yang menandakan tingkat kebugaran tubuh siswa, yang dapat memengaruhi semangat dan intensitas belajar siswa dalam mengikuti pelajaran. Pada aspek fisiologis siswa kelas $\mathrm{V}$ menunjukkan bahwa siswa memiliki kondisi kebugaran jasmani yang cukup baik, sehingga seharusnya siswa memiliki intennsitas minat belajar yang tinggi. Selanjutnya pada aspek psikologis berdasarkan hasil pernyaataan wawancara narasumber dari guru, siswa dan orang tua menunjukkan bahwa siswa kurang memiliki minat terhadap pembelajaran matematika. Siswa tidak memperhatikan guru pada saat pembelajaran. Ketika berada dirumah, siswa bila disuruh untuk belajar biasanya hanya belajar sebentar ketika orang tuanya lengah akan berhenti belajar.

Ada tidaknya minat siswa juga dapat dilihat berdasarkan sikap dan perhatian siswa dalam mengikuti pembelajaran. Dalyono (2010:235) mengatakan bahwa minat dapat dilihat dari cara anak dalam mengikuti pelajaran serta memperhatikan tidaknya dalam pembelajaran tersebut. Berdasarkan hasil wawancara tersebut menunjukkan bahwa siswa kurang memperhatikan guru pada saat pembelajaran. Hal ini dapat menjelaskan bahwa siswa memiliki minat yang rendah terhadap mata pelajaran matematika. Pernyataan ini juga dapat diperkuat dengan pendapat Kartika (2014) yang menyebutkan salah satu indikator minat belajar yaitu dapat dilihat dari aspek keterlibatan yang menunjukkan bentuk siswa dalam mengukiti proses pembelajaran.

Faktor Eksternal Faktor eksteren merupakan faktor yang berasal dari luar. Faktor ektern terdiri dari guru, orang tua, dan lingkungan belajar. Berdasarkan hasil wawancara dapat diketahui bahwa dalam menyampaikan pembelajaran guru jarang menggunakan media pembelajaran. Pada saat menyampaikan pembelajaran guru hanya menggunakan buku siswa dari pemerintah serta LKS. Guru tidak menggunakan sumber yang lain untuk menunjang pembelajaran.

Dari hasil penelitian dapat diketahui bahwa faktor ekstern rendahnya minat belajar siswa kelas V pada mata pelajaran dapat dilihat dari faktor guru. Pada penelitian ini menunjukkan bahwa faktor ekstern rendahnya minat belajar siswa pada mata pelajaran matematika dilihat dari segi faktor guru dapat diketahui bahwa guru dalam menyampaikan materi pembelajaran terlalu biasa. Sehingga siswa menjadi kurang tertarik dalam mengikuti pembelajaran. Hal ini sejalan dengan Hadist dan Nurhayati (2010:45) yang menyatakan bahwa minat belajar peserta didik dipengaruhi oleh pendekatan pembelajaran yang digunakan oleh guru, sikap dan perilaku guru, media pembelajaran, fasilitas pembelajaran, lingkungan belajar, suara guru, dan lainnya. Dilihat dari segi orang tua Berdasarkan hasil wawancara menunjukkan bahwa orang tua sering memarahi siswa ketika mendapat nilai yang kurang. Pada saat di rumah orang tua siswa akan memarahi anaknya ketika tahu bahwa nilai hasil belajar yang didapatkan kurang. Sikap orang tua siswa dalam menanggapi anaknya ketika mendapatkan nilai yang kurang baik akan berakibat terhadap sikap siswa dalam belajar.

Hal ini bertolak belakang dengan pendapat Widiasworo (2017:20) yang menyatakan bahwa siswa akan tertarik dalam belajar apabila mendapatkan perhatian dari orang tua. Pernyataan dari hasil penelitian telah menunjukkan bahwa kurang tepatnya cara didikan orang tua terhadap anaknya. Selanjutnya dilihat berdasarkan faktor lingkungan dari hasil pengamatan dan wawancara dengan orang tua, dan guru lingkungan disekitar gedung sekolah dan tempat tinggal siswa terbilang cukup mendukung untuk belajar. Pernyataan tersebut sesuai dengan yang dinyatakan oleh Syah (2011:145) lingkungan nonsosial merupakan lingkungan yang terdiri dari gedung sekolah dan letaknya, rumah temapat tinggal siswa, alat-alat belajar, keadaan cuaca, dan waktu 
belajar yang digunakan siswa. Berdasarkan hasil penelitian menunjukkan bahwa linkungan belajar baik dari segi temapat serta letak sekolah, sangat mendukung terhadap belajar siswa.

2. Upaya guru dalam meningkatkan belajar siswa pada mata pelajaran matematika.

Berdasarkan dari hasil pengamatan dan wawancara dapat diketahui bahwa upaya yang dilakukan oleh guru dalam menumbuhkan minat belajar siswa sudah cukup baik. Namun guru belum melaksanakan secara maksimal. Upaya guru dalam menumbuhkan minat belajar siswa dengan cara memberikan soal dan mencongak memang sudah cukup baik. Namun akan lebih menarik lagi apabila guru dalam menyampaikan materi pembelajaran matematika pada siswa menggunakan media pembelajaran. Pernyataan tersebut juga disampaikan oleh Widiasworo (2017:25) yang menyatakan bahwa upaya yang dapat dilakukan oleh guru dalam menumbuhkan minat belajar siswa yaitu penggunaan media pembelajaran dalam setiap kegiatan pembelajaran serta perlunya sikap guru yang hangat dan kooperatif. Seperti halnya penelitian yang dilakukan oleh Paseleng, M. C., \& Arfiyani, R (2015) dengan judul Pengimplementasian Media Pembelajaran Berbasis Multimedia Interaktif Pada Mata Pelajaran Matematika di Sekolah Dasar. Hasil dari penelitian ini dapat disimpulkan bahwa media pembelajaran berbasis multimedia interaktif memberikan pengaruh positif terhadap pembentukan minat belajar siswa khususnya pada mata pelajaran. Hal ini dapat dijadikan sebagai refrensi guru dalam melakukan pembelajaran yang akan datang untuk dapat menumbuhkan minat belajar siswa, khususnya pada mata pelajaran matematika.

\section{Kesimpulan}

Faktor yang memperngaruhi rendahnya minat belajar matematika siswa V diantaranya yaitu faktor internal dan eksternal. Faktor internal merupakan faktor yang berasal dari dalam diri siswa. Faktor intern terdiri dari aspek fisiologis dan aspek psikologis. Faktor psikologis yang berasal dari dalam diri siswa lebih mendominasi dibanding dengan faktor jasmaniah. Sementara faktor psikologis itu sendiri terdiri dari perhatian siswa, tingkat kecerdasan dan sikap siswa terhadap pembelajaran. Faktor lain yang mempengaruhi masih rendahnya minat belajar siswa yaitu faktor eksternal. Faktor eksternal merupakan faktor yang berasal dari luar. Faktor ekternal merupakan faktor yang meliputi cara guru mengajar, sikap, perhatian dan cara didikan orang tua, serta fasilitas dalam pembelajaran.

Upaya yang didapat dlakukan oleh guru dalam menumbuhkan minat belajar siswa terkait dengan faktor yang melatarbelakangi rendahnya minat belajar siswa dapat dilakukan dengan beberapa cara. Salah satu cara yang dapat dilakukan oleh guru antara yaitu dengan menggunakan media pembelajaran dan metode mengajar yang lebih bervariatf. Sehingga akan membuat siswa tertarik dan memilki minat dalam pembelajaran matematika.

\section{Daftar Pustaka}

Ali, M dan Asrori, M. (2014). Metodelogi dan Aplikasi Riset Pendidikan. Jakarta: PT Bumi Aksara

Dalyono, M. (2010). Psikologi Pendidikan. Jakarta: PT Rineka Cipta

Hadis, A dan Nurhayati. (2010). Psikologi dalam Pendidikan. Bandung: Alfabeta.

Kartika, H. (2014). Pembelajaran Matematika Berbantuan Software MatLab sebagai Upaya Meningkatkan Kemampuan Komunikasi Matematis dan Minat Belajar Siswa SMA. JUDIKA (Jurnal Pendidikan Unsika), 2(1). 
Nahdi, D. S. (2017). Implementasi Model Pembelajaran Collaborative Problem Solving Untuk Meningkatkan Kemampuan Representasi Matematis Siswa Sekolah Dasar. Jurnal Cakrawala Pendas. 3 (1). hal. 20-29.

Paseleng, M. C., \& Arfiyani, R. (2015). Pengimplementasian media pembelajaran berbasis multimedia interaktif pada mata pelajaran matematika di sekolah dasar. Scholaria: Jurnal Pendidikan Dan Kebudayaan, 5(2), 131-149.

Silviani, T.R. (2017). Upaya Meningkatkan Minat Belajar Matematika Menggunakan Inquiry Based Learning Setting Group Investigation. Kreano. 8 (2) (2017): 150-161

Sirait, E. D. (2016). Pengaruh Minat Belajar Terhadap Prestasi Belajar Matematika. Jurnal Formatif. $6(1): 35-43$

Sugiyono. (2010). Metode Penelitian Pendidikan, Pendekatan Kuantitatif, Kualitatif, dan R\&D. Bandung: Alfabeta.

Susanto, A. (2013). Teori Belajar dan Pembelajaran di Sekolah Dasar. Jakarta: Kencana Prenadamedia Group

Syah, M. (2011). Psikologi Belajar. Jakarta: PT RajaGrafindo Persada

Widiasworo, Erwin. (2017). Masalah-masalah Peserta Didik dan Solusinya. Yogyakarta: Araska 